\title{
Reproductive biology aspects of two species of the genus Gavilea (Orchidaceae, Chloraeinae) in populations from Central Chile
}

\section{Aspectos de la biología reproductiva de dos especies del género Gavilea (Orchidaceae, Chloraeinae) en poblaciones de Chile central}

\author{
Carlos E. Valdivia ${ }^{1}$, Mauricio A. Cisternas ${ }^{2}$ \& Gabriela S. Verdugo ${ }^{2}$ \\ 1Departamento de Ciencias Ecológicas, Facultad de Ciencias, Universidad de Chile. Casilla 653, Santiago, Chile. \\ ${ }^{2}$ Escuela de Agronomía, Pontificia Universidad Católica de Valparaíso. Casilla 4-D, Quillota, V Región, Chile. \\ cvaldiviap@yahoo.com
}

\begin{abstract}
The extent to which plants depend on pollinators for outcross pollen transportation is a key issue in plant reproductive ecology. We evaluated the putative breeding system, floral display, and natural pollination in two Southern Cone of South American orchids, Gavilea araucana and G. venosa, by performing four hand pollination trials (agamospermy, autogamy, geitonogamy, and xenogamy tests) and by counting each flower and fruit produced by plants in natural conditions. Fruit set differed significantly depending on the origin of pollen as well as on the presence of a pollen vector. None of these species produced fruits by the agamospermy tests, therefore indicating that they require the presence of pollen on the stigmas for fruit setting. By contrast, only G. araucana was capable of fruit setting following the autogamy test, therefore demostrating that this orchid needs not depend on pollinators for fruit set. Furthermore, G. araucana and $G$. venosa produced $100 \%$ fruits by geitonogamy and by xenogamy, thereby indicating that both plants are totally self-compatible. The mean number of flowers per plant was 2.1 times higher in G. venosa with respect to G. araucana; however, natural fruiting success was $28.8 \%$ and $98.9 \%$, respectively. Furthermore, while the increase in fruiting success significantly and positively correlated with an increase in floral display in G. araucana, in G. venosa these variables were unrelated. Certainly, further studies concerning the reproductive strategies in orchids of southern South America are of great importance.
\end{abstract}

KEYWORDS: Autogamy, allogamy, self-compatibility, floral display, fruiting patterns.

\section{RESUMEN}

El alcance al cual las plantas dependen de polinizadores para el transporte de polen para los exocruzamientos es uno de los temas claves en ecología reproductiva de las plantas. Evaluamos el sistema reproductivo potencial, despliegue floral y polinización natural en dos orquídeas del Cono Sur de Sudamérica, Gavilea araucana y G. venosa, efectuando cuatro ensayos de polinización manual (agamospermia, autogamia, geitonogamia y xenogamia) y contando cada flor y fruto producidos por las plantas en condiciones naturales. La producción de frutos difirió significativamente dependiendo del origen del polen así como de la presencia de un vector polínico. Ninguna de las especies produjo frutos en las pruebas de agamospermia indicando, por lo tanto, que ellas requieren de la presencia de polen en los estigmas para producir frutos. Por el contrario, solamente G. araucana fue capaz de producir frutos siguiendo la prueba de autogamia demostrando, por ende, que esta orquídea no necesita depender de polinizadores para producir frutos. Además, G. araucana y G. venosa produjeron un $100 \%$ de frutos por geitonogamia y xenogamia, indicando esto, que ambas plantas son autocompatibles. El número promedio de flores por planta fue 2,1 veces mayor en $G$. venosa con respecto a G. araucana; sin embargo, el éxito en la fructificación natural fue de $28,8 \%$ y $98,9 \%$, respectivamente. Además, mientras el incremento en el éxito de la fructificación se correlacionó positiva y significativamente en G. araucana, en G. venosa estas variables no estuvieron relacionadas. Ciertamente, estudios adicionales referidos a las estrategias reproductivas de las orquídeas del sur de Sudamérica son de gran importancia.

Palabras clave: Autogamia, alogamia, autocompatibilidad, despliegue floral, patrones de fructificación. 
Contrasting breeding systems, floral displays, and fruiting patterns in Gavilea: VALDIVIA, C.E. ET AL.

\section{INTRODUCTION}

The degree of dependency of plants on pollinators for outcross pollen transportation is a key issue in plant reproductive ecology because it may constrain the evolutionary trajectories of plants and their pollinators. The breeding system and pollination of a species determine the ways whereby seeds will be produced, and the degree of dependency of plants on pollinators for seed set (LovettDoust \& Lovett-Doust 1988, Richards 1997).

Orchids, with their unusual pollination mechanisms attracted the attention of Darwin (1877), who argued that they offer strong evidence both for natural selection and for the advantages of cross-pollination. Since then, much effort has been devoted to describing orchid pollination mechanisms and breeding systems (e.g. van der Pijl \& Dodson 1966, Neiland \& Wilcock 1998, Tremblay et al. 2005). Currently, it is well known that during the origin of Orchidaceae in the Cretaceous, most angiosperm flowers would have been visited by unspecialized insects like beetles and flies, which pollinated them while feeding on both floral and vegetative tissues (Proctor et al. 1996, Neiland \& Wilcock 1998). The most likely origin of highly adapted mechanisms among nectarless orchids is that they arose from primitive orchids, which had even lower levels of fruit set than seen today, probably owing to the existence of unspecialized and largely unrewarding flowering environments (Neiland \& Wilcock 1998). Thus, a small adaptation that improved pollinator attraction would have had a reproductive advantage and would have increased in frequency. Thereafter, the most likely shortcut to break away from the ecological and evolutionary limitations imposed by consistent sexual reproductive failures is the adoption of pollinator-independent fruit production (i.e. autogamy and/ or agamospermy), or the provision of rewards in order to entice pollinators (Neiland \& Wilcock 1998). Nevertheless, agamospermy is infrequent in orchids because it may be inhibited since embryo-sac formation in the family is unusual in requiring the presence of pollen on the stigma as a stimulus, while autogamy, in spite of being more widespread, is probably morphologically prevented in most orchids by the herkogamous structure of flowers (Neiland \& Wilcock 1998, Proctor et al. 1996). Therefore, the way usually adopted by orchids in order to ensure a successful fruit set is to produce nectar for pollinator enticing, thus precluding autogamy or agamospermy as possible pathways for seed set (Proctor et al. 1996, Neiland \& Wilcock 1998).

Nevertheless, when deceptive plants are not capable of producing nectar for pollinator attraction, the way adopted for ensuring reproductive success in pollinatorlimited orchids is the increase in floral display (i.e. number of flowers per plant) which usually translate into an increase in the frequency of pollinator visits and a higher fruit and seed production (Tremblay et al. 2005).
In fact, this has been largely documented in orchids of the genera Anacamptis, Brassavola, Calopogon, Orchis, and Platanthera (Schemske 1980, Firmage \& Cole 1988, Zimmerman \& Aide 1989, Calvo 1990, Fritz \& Nilsson 1996, Maad 2000). Certainly, the mechanism involved in such an increase in floral display is the selection pressure exerted by pollinators on the number of flowers per individual plants (Tremblay et al. 2005).

The genus Gavilea ranges in southern South America and in Chile is represented by 12 species (Novoa et al. 2006). Only the breeding system of G. lutea has partially been studied by Arroyo \& Squeo (1990), thereby the reproductive behaviour of a vast majority of the Gavilea species remains largely unknown. The aim of this work is to evaluate the putative breeding system, floral display, and fruiting patterns of G. araucana (Phil.) M.N.Correa and $G$. venosa (Lam.) Garay et Ormd. by experimentally performing a suite of pollination trials in one population of each species, as a first approach to reproductive strategies of orchids belonging to this genus.

\section{METHODS}

NATURAL HISTORY

Fieldwork was conducted at Los Queules National Reserve (35 $\left.09^{\circ} \mathrm{S}, 72^{\circ} 41^{\prime} \mathrm{W}\right)$ and Río Clarillo National Reserve (33 $\left.41^{\prime} \mathrm{S}, 70^{\circ} 24^{\prime} \mathrm{W}\right)$ in the Mediterranean zone of central Chile. In Los Queules National Reserve, the study was conducted from November 2006 to January 2007, a period corresponding to the assessment of breeding system in $G$. araucana; and from November 2007 to January 2008, a period corresponding to the assessment of floral display and natural fruiting in the same species (see below). In Río Clarillo National Reserve, the study was conducted from October to December 2007, a period corresponding to the assessment of breeding system and floral display and natural fruiting in G. venosa (see below). Vegetation comprises Mediterranean coastal deciduous forests of Nothofagus glauca and Persea lingue at Los Queules N.R., and Mediterranean Andean sclerophyllous forests of Quillaja saponaria and Lithrea caustica at Río Clarillo N.R. (Luebert \& Pliscoff 2006). Gavilea araucana is found in the former vegetation belt, whereas $G$. venosa is found in the latter vegetation type. Gavilea araucana and $G$. venosa (Orchidaceae, Chloraeinae) are geophytic orchids widely distributed in forests from Chile (from c. $33^{\circ} \mathrm{S}$ to $51^{\circ} \mathrm{S}$ in $G$. araucana, and from c. $30^{\circ} \mathrm{S}$ to $41^{\circ} \mathrm{S}$ in G. venosa) (Novoa et al. 2006). Both species exhibit pauciflorous inflorescences with conspicuous white-coloured flowers bearing a smallsized yellow-coloured labellum (Fig. 1). Flowering and fruiting occur from November to January in G. araucana and from September to November in G. venosa, in the austral spring-time season (Novoa et al. 2006). 


\section{BREEDING SYSTEMS}

To determine the putative breeding system of G. araucana and $G$. venosa, four pollination trials were conducted (Kearns \& Inouye 1993). In these species, each treatment was performed in 21 flowers equally distributed in 10 and 7 individual plants of $G$. araucana and $G$. venosa, respectively. To test whether these orchids are capable of fruit setting in the absence of pollen (i.e. agamospermy), an apomixis test was performed on flower buds which were emasculated (i.e. anther excision) and bagged until seed dispersal in order to prevent any flower-pollinator interaction. Similarly, to test whether these orchids are capable of fruit setting after receiving pollen from the same flower in the absence of pollinators carrying pollen within the flower (i.e. autogamy), an automatic self-pollination test was performed by bagging non-emasculated flower buds until seed dispersal. To test whether these orchids are capable of fruit setting with pollen of the same individual carried by pollinators (i.e. geitonogamy), a test was performed by bagging flower buds which were previously emasculated and hand cross-pollinated with endogenous pollen at the stigmatic receptivity time. Another test was performed by bagging emasculated flower buds which, at the stigmatic receptivity time, were hand cross-pollinated with exogenous pollen in order to test whether these orchids are capable of fruit setting with pollen from other individuals (i.e. xenogamy).

The results of these treatments were recorded by checking the ratio of fruits produced per crossed flower when the ovaries were ripe, prior to seed dispersal. Thereafter, to determine the degree of self-incompatibility, the index of self-incompatibility (ISI) was determined as the proportion of fruits produced by geitonogamy and by xenogamy (Ruiz-Zapata \& Arroyo 1978). The ISI ranges between 0 (self-incompatibility) and 1 (self-compatibility) (Ruiz-Zapata \& Arroyo 1978).

Each orchid species was assessed independently. Analyses of breeding systems were performed on a perflower basis by evaluating means of generalised linear models with a binomial error distribution and logit link functions, after Bonferroni corrections. All analyses were performed using the Statistica software package v. 6.0.
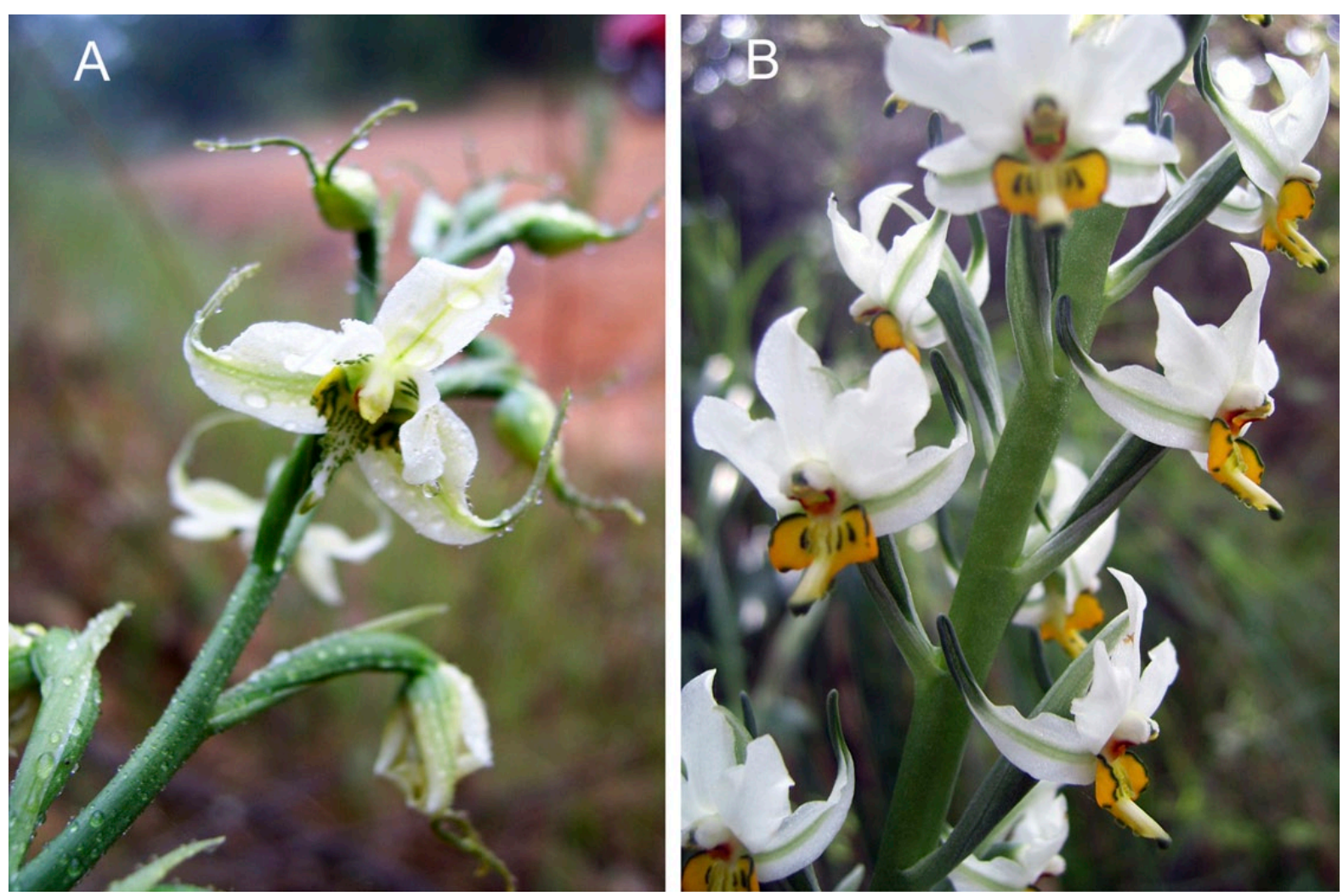

Figure 1. Gavilea araucana (A) and G. venosa (B) thriving at Los Queules National Reserve and Río Clarillo National Reserve at central Chile.

Figura 1. Gavilea araucana (A) y G. venosa (B) habitando en las Reservas Nacionales Los Queules y Río Clarillo, respectivamente, en Chile central. 
Contrasting breeding systems, floral displays, and fruiting patterns in Gavilea: ValdiviA, C.E. ET AL.

FLORAL DISPLAY AND NATURAL POLLINATION

Floral display, assessed as the total number of flowers per individual plant, was estimated by inconspicuously tagging plants at the vegetative stage and counting the total number of flowers produced by such plants at the end of the flowering season. The total number of plants corrresponded to nearly all plants growing at each study site ( 9 plants of $G$. araucana, and 43 plants of $G$. venosa). While G. araucana was checked in January 2008, $G$. venosa was checked in December 2007. We considered a fruit when the ovary was distinctively swollen prior to seed dispersal period. Thereafter, floral display and fruiting success were compared between both orchid species through non-parametric Mann-Whitney Tests, and then related through a regression analysis in each species. Both types of analyses were performed using the Statistica software package v. 6.0.

\section{RESULTS}

BREEDING SYSTEMS

Fruit set differed significantly depending on the origin of pollen as well as on the presence of a pollen vector in $G$. araucana and $G$. venosa. In fact, none of these orchids produced fruits by the agamospermy tests, therefore indicating that both species require the presence of pollen on the stigmas for fruit setting (Fig. 2). On the contrary, while $G$. araucana was capable of fruit setting following the autogamy test, $G$. venosa was not capable of fruit setting through the same trial, therefore demostrating that the former need not depend on pollinators for fruit set (Fig. 2 ). In both species floral visitors and pollinators are not yet known. Furthermore, both orchids produced $100 \%$ fruits by geitonogamy and by xenogamy, thereby indicating that both plants are totally self-compatible (Fig. 2). In fact, the ISI values attained for both species were 1.00.

\section{FLORAL DISPLAY AND NATURAL POLLINATION}

The mean number of flowers per plant was 2.1 times higher in $G$. venosa with respect to G. araucana (Mann-Whitney Test: $\mathrm{U}=44.00 ; P<0.001$ ) (Fig. 3). Nevertheless, the mean number of fruits per plant was 1.9 times higher in $G$. araucana with respect to $G$. venosa $(\mathrm{U}=55.50 ; P<0.001)$ (Fig. 3). In fact, fruiting success attained by G. araucana and G. venosa was $98.9 \%$ and $28.8 \%$, respectively. Furthermore, while the increase in fruiting success significantly correlated with an increase in floral display in $G$. araucana (ProductMoment Pearson Regression Test: $\left.\mathrm{R}^{2}=0.99 ; P<0.001\right)$, in $G$. venosa was unrelated $\left(\mathrm{R}^{2}=0.04 ; P=0.222\right)$ (Fig. 4).

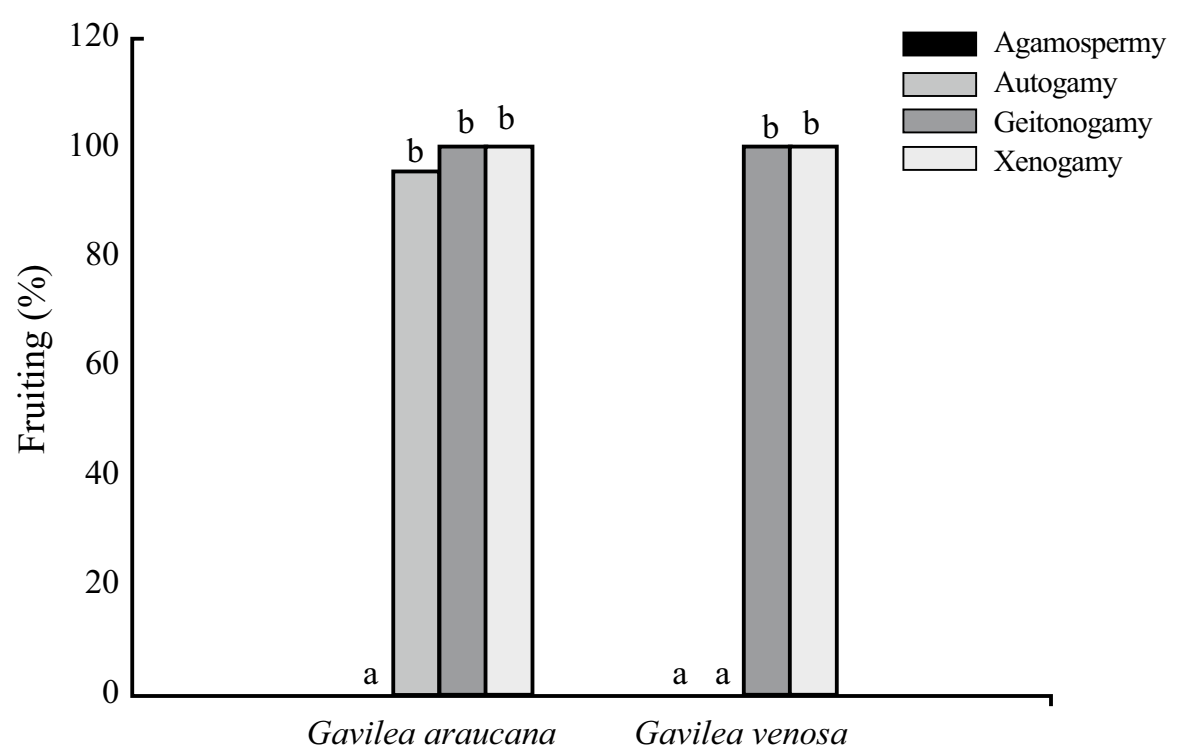

FIGURE 2. Female reproductive success, assessed as percentage of fruiting, in Gavilea araucana and G. venosa in central Chile, following four hand pollination trials. Dissimilar letters depict significant differences (Generalised Linear Models with a binomial error distribution and logit link functions: $P<0.017$, after Bonferroni corrections).

FIgURA 2. Éxito reproductivo femenino, evaluado como el porcentaje de fructificación, de Gavilea araucana y G. venosa en Chile central, luego de cuatro ensayos de polinización manual. Letras disímiles representan diferencias significativas (Modelo Generalizado Lineal con una distribución de error binomial y función de ligamiento logit: $P<0,017$, después de las correcciones de Bonferroni). 
Gayana Bot. 67(1), 2010

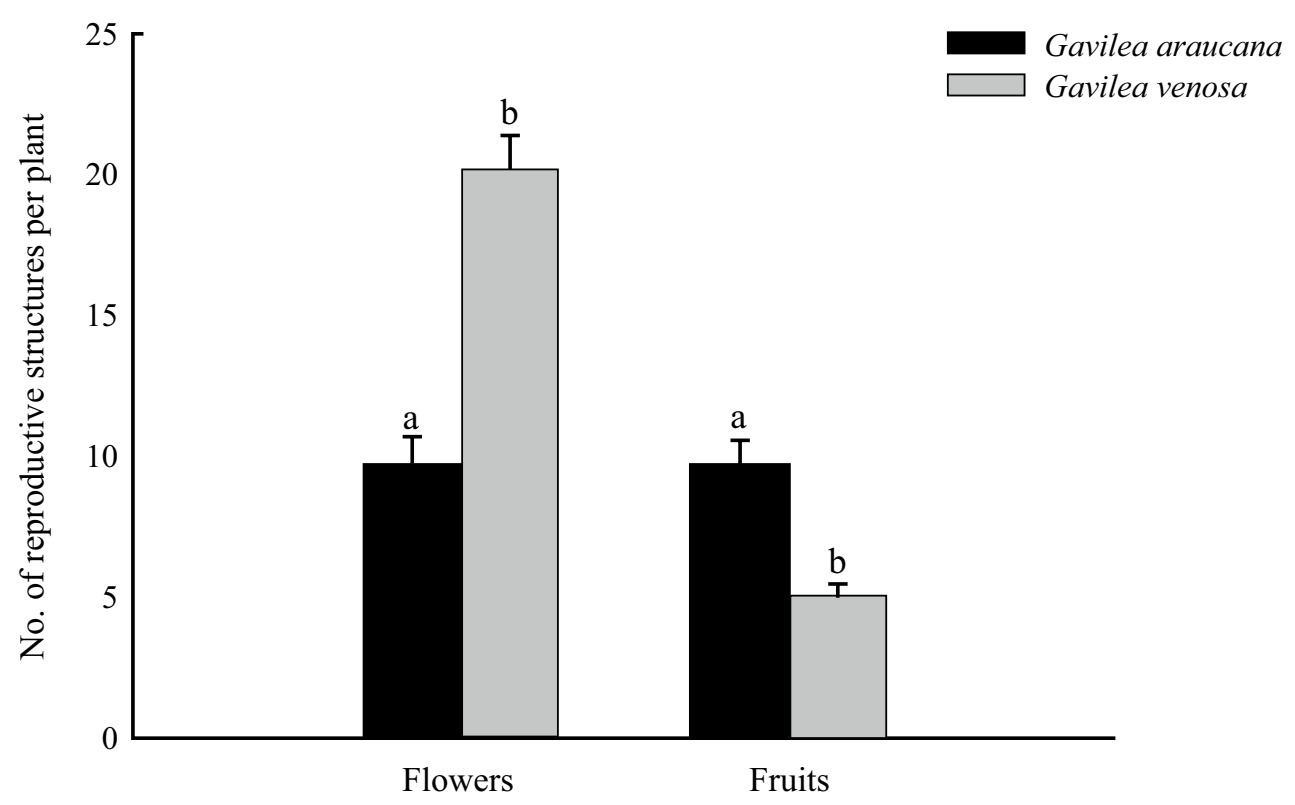

FIGURE 3. Floral display, assessed as the number of flowers per plant, and female reproductive success, assessed as the percentage of fruiting, in Gavilea araucana and G. venosa in central Chile (Mean $\pm 1 \mathrm{SE}$ ). Dissimilar letter depict significant differences (MannWhitney Tests: $P<0.05)$.

Figura 3. Despliegue floral, evaluado como el número de flores por planta, y el éxito reproductivo femenino, evaluado como el porcentaje de fructificación, en Gavilea araucana y G. venosa en Chile central (Media $\pm 1 \mathrm{SE}$ ). Letras disímiles representan diferencias significativas (Pruebas de Mann-Whitney: $P<0,05$ ).

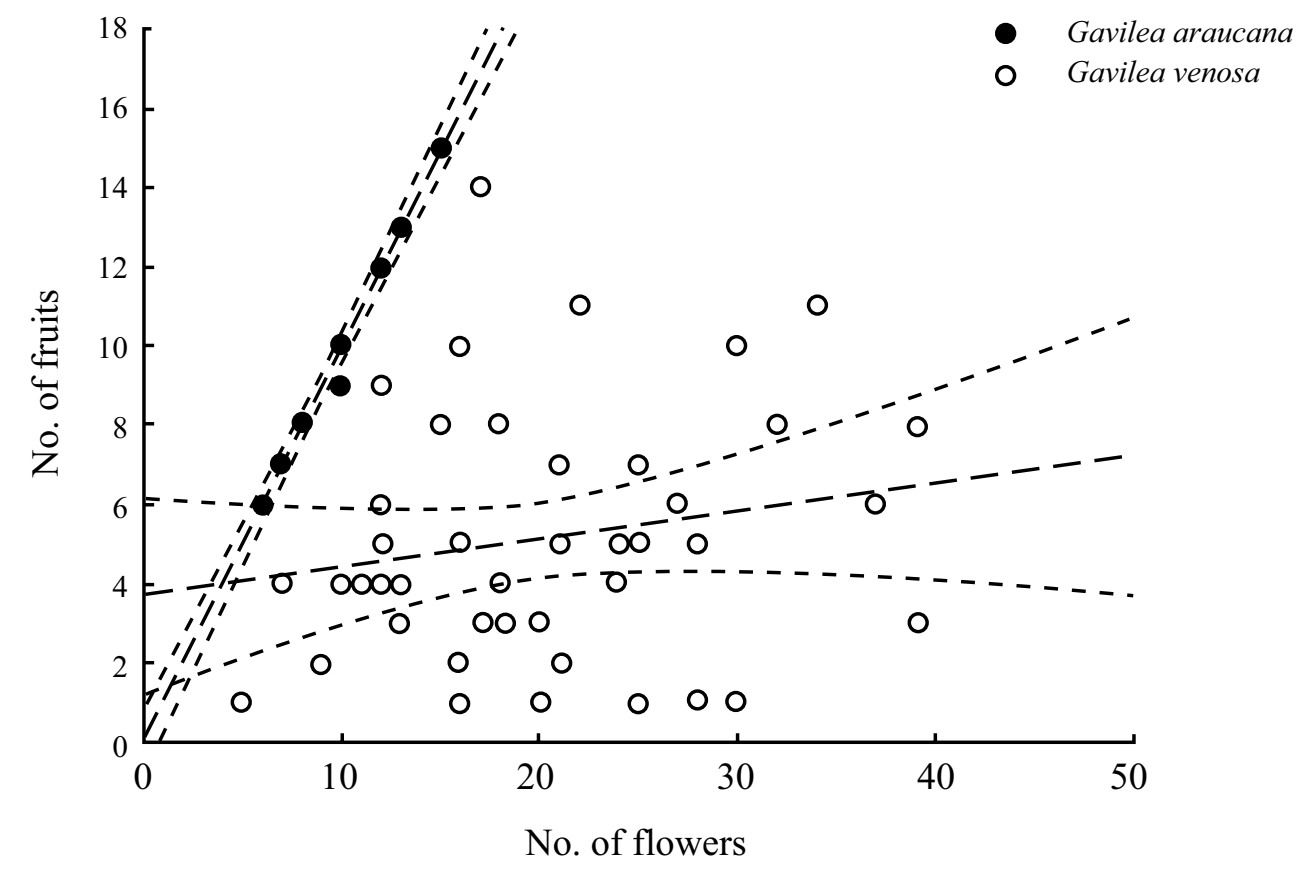

FIGURE 4. Relationships between floral display, in terms of flower number per plant, and female reproductive success of Gavilea araucana and G. venosa in central Chile. Dashed lines correspond to regression curves \pm confidence intervals at $95 \%$ level (Regression equations: $y=0.997 x-0.082$ for G. araucana, and $y=0.070 x+3.705$ for $G$. venosa).

FIGURA 4. Relación entre el despliegue floral, en términos del número de flores por planta, y el éxito reproductivo de Gavilea araucana y $G$. venosa en Chile central. Líneas punteadas corresponden a las curvas de regresión \pm intervalo de confianza al 95\% (Ecuaciones de regresión: $y=0,997 x-0,082$ para G. araucana, e $y=0,070 x+3,705$ para G. venosa). 
Contrasting breeding systems, floral displays, and fruiting patterns in Gavilea: ValdiviA, C.E. ET AL.

\section{DISCUSSION}

Breeding systems, floral displays, and fruiting patterns differed significantly in both Gavilea orchids herein assessed, therefore indicating that at least two reproductive strategies have evolved in this genus. While G. araucana may exhibit a pollinator-independent fruit production (i.e. an autonomously selfed plant), $G$. venosa needs the action of a pollen vector for fruit and seed setting. Both strategies lead plants to dissimilar costs and benefits (Lloyd 1988). One result of autogamy is that pollination limitation may be reduced (depending on the degree to which the pollen of a single flower can fertilize all potential ovules) or absent and the evolution of self-fertilization under these conditions might follow the Reproductive Assurance Hypothesis of Hagerup (1952) and Jain (1976) (but see Eckert et al. 2006, Pannell 2006). In this regard, models for the evolution of self-fertilization indicate that selfing variants should be selected over outcrossers as long as selfed progeny are at least half as fit as outcrossed progeny (Lande \& Schemske 1985, Charlesworth \& Charlesworth 1987, Lloyd 1988). This outcome assumes that seed set is not pollen-limited and requires that self-pollination does not reduce outcrossed siring by the selfing variant compared with outcrossing parents, i.e., no pollen discounting (Harder \& Wilson 1998). Nevertheless, when pollination is limited by the availability of mates or pollinators, as seemingly occurs in both orchids herein assessed, self-fertilization may evolve even in the presence of high inbreeding depression, as long as the selfed ovules would not otherwise have been outcrossed, i.e., no seed discounting (Lloyd 1992, Herlihy \& Eckert 2002). The relative importance of both pollen and seed discounting depends largely on the mode of self-fertilization (Lloyd 1992). Delayed selfing, which occurs without the need of pollinator service, should confer the greatest advantage for reproductive assurance in species like G. araucana which is totally self-compatible and fully capable of seed setting in absence of pollinators. By contrast, geitonogamy -the other mode of self-fertilization- cannot evolve in populations at demographic equilibrium, except as the indirect outcome of selection to increase outcrossing, because geitonogamy involves complete pollen and seed discounting. Furthermore, geitonogamy requires the action of a pollen vector and so offers no reproductive assurance in allogamous species like $G$. venosa if no pollinator is present in spite of being totally self-compatible (Lloyd 1992, Pannell 2006).

Autogamy is less frequent among orchids than allogamy, although it may vary across different regions. Accordingly, van der Pijl \& Dodson (1966) estimated the family-wide occurrence of autogamy to be about $3 \%$, although recent estimates from local floras suggest it may be higher. For instance, Catling (1990) suggested that autogamy may occur in between $5 \%$ and $20 \%$ of the family. Ackerman (1985) estimated that $15 \%$ of the North
American orchid flora was autogamous compared to $10 \%$ for Barro Colorado Island, Panama and 25\% for Puerto Rico. Furthermore, there is evidence that autogamy increases with latitude and in insular areas. In eastern Canada, for example, $17 \%$ of orchids are autogamous, while values for Europe range from 27 to 50\% (Hagerup 1952, Catling 1990). Self-pollination is more frequent in austere colder habitats (Catling 1990 and references therein) where pollinator activity might be unpredictable. In the case of Gavilea, the southernmost G. araucana exhibited a pollinator-independent fruit production, which strongly differ with $G$. venosa whose reproductive success totally depend on these mutualists. This fact might indicate the same trend in the southern hemisphere and at the intrageneric level. In fact, in spite of contrasting breeding systems among species of the same genus have been reported for orchids of the genus Liparis from North America and Asia (Whigham \& O'Neil 1991, Oh et al. 2001), no previous work has been reported for the South American terrestrial orchids.

Gavilea araucana exhibited a higher percentage of fruit set than the mean number previously reported for other orchids. Among them in which mechanisms of selfpollination are known, average fruit set is high: $77.0 \pm$ $5.0 \%$ (between $14 \%$ and $100 \%, \mathrm{~N}=21$, see Tremblay et al. 2005), much higher than it is in allogamous orchids. This fact strongly suggests that fruit production in $G$. araucana is not resource-limited as often occurs in other species (Tremblay et al. 2005).

Gavilea venosa, by contrast, exhibited a totally pollinator-dependent breeding system, which is in agreement with other orchids of the tribe Chloraeinae in southern South America (Clayton \& Aizen 1996, Lehnebach \& Riveros 2003, Ciotek et al. 2006, Humaña et al. 2008). Furthermore, $G$. venosa bears greater floral displays which may be interpreted as a consequence of pollinator-mediated selection. Nevertheless, increaments in floral display in a per-individual basis did not translate into an increase in fruit set, thus indicating that pollinators did not act as selective agents on this trait for the period herein assessed. Certainly, determining whether this trait contribute to an increase in reproductive success in other reproductive seasons would clarify the adaptive value of this feature. At the population level, however, natural fruiting in $G$. venosa was roughly the same as that of other nectarless orchids around the world, which is lower than that observed in rewading species (Tremblay et al. 2005).

Contrasting breeding systems, floral displays, and fruit sets reported in this narrow-scaled study certainly encourage further investigations concerning reproductive strategies in orchids of southern South America. Despite some recent researches (Clayton \& Aizen 1996, Lehnebach \& Riveros 2003, Ciotek et al. 2006, Humaña et al. 2008), there is still much more to be done. 


\section{ACKNOWLEDGEMENTS}

We thank Javier A. Simonetti, Cristian Romero, Paulina González, Sergio Hernández, and Brenda Valdivia for their valuable support during fieldwork. This work was partially funded by Beca de Apoyo a la Realización de Tesis Doctoral, CONICYT (CEV).

\section{REFERENCES}

ACKerman, J.D. 1985. Pollination of tropical and temperate orchids. In: K.W. Tan (ed.), Proceedings of the eleventh world orchid conference, pp: 98-101, Miami.

Arroyo, M.T.K. \& F.A. Squeo. 1990. Relationship between plant breeding systems and pollination. In: S. Kawano (ed.), Biological Approaches and Evolutionary Trends in Plants, pp: 205-227. Academic Press, London.

CALvo, R.N. 1990. Inflorescence size and fruit distribution among individuals of three orchid species. American Journal of Botany 77: 1378-1381.

Catling, P.M. 1990. Auto-pollination in the Orchidaceae. In: J. Arditti (ed.), Orchid Biology: Reviews and Perspectives, V, Portland, OR, pp: 121-158. Timber Press.

Charlesworth, D. \& B. Charlesworth. 1987. Inbreeding depression and its evolutionary consequences. Annual Review of Ecology and Systematics 18: 237-268.

Ciotek, L., P. Giorgis, S. Benítez-Vieyra \& A.A. Cocucci. 2006. First confirmed case of pseudocopulation in terrestrial orchids of South America: Pollination of Geoblasta pennicillata (Orchidaceae) by Campsomeris bistrimacula (Hymenoptera, Scoliidae). Flora 201: 365-369.

Clayton, S. \& M. Aizen. 1996. Effects of pollinia removal and insertion on flower longevity in Chloraea alpina (Orchidaceae). Evolutionary Ecology 10: 653-660.

DARwIN, C. 1877 . The various contrivances by which orchids are fertilized by insects. Chicago: University of Chicago Press. (1984 ed.).

ECKert, C.G., K.E. SAmis \& S. DART. 2006. Reproductive assurance and the evolution of uniparental reproduction in flowering plants. In: L.D. Harder \& S.C.H. Barrett (eds.), Ecology and Evolution of Flowers, pp. 183-203. Oxford University Press.

Firmage, D.H. \& F.R. Cole. 1988. Reproductive success and inflorescence size of Calopogon tuberosus (Orchidaceae). American Journal of Botany 75: 1371-1377.

Fritz, A.-L. \& L.A. Nilsson. 1996. Reproductive success and gender variation in deceit-pollinated orchids. In: D.G. Lloyd \& S.C.H. Barrett (eds.), Floral Biology, Studies on Floral Evolution in Animal-Pollinated Plants, pp. 319338. Chapman and Hall, New York.

Hagerup, O. 1952. Bud autogamy in some northern orchids. Phytomorphology 2: 51-60.

Harder, J.D. \& W.G. Wilson. 1998. A clarification of pollen discounting and its joint effects within inbreeding depression on mating system evolution. American Naturalist 152: 684-695.

Herlihy, C.R. \& C.G. Eckert. 2002. Genetic costs of reproductive assurance in a self-fertilizing plant. Nature 416: 320-323.
Humaña, A.M., M.A. Cisternas \& C.E. Valdivia. 2008. Breeding system and pollination of selected orchids of the genus Chloraea from central Chile. Flora 203: 469-473.

JAIN, S.K. 1976. The evolution of inbreeding in plants. Annual Review of Ecology and Systematics 7: 469-495.

Kearns, C.A. \& D.W. Inouye. 1993. Techniques for Pollination Biologists. Colorado, U.S.A: University Press of Colorado. Colorado. xviii $+582 \mathrm{pp}$.

Lande, R. \& D.W. Schemske. 1985. The evolution of selffertilization and inbreeding depression in plants I. Genetic models. Evolution 39: 24-40.

Lehnebach, C.A. \& M. Riveros. 2003. Pollination biology of the Chilean endemic orchid Chloraea lamellata. Biodiversity and Conservation 12: 1741-1751.

LLOYD, D.G. 1988. Benefits and costs of biparental and uniparental reproduction in plants. In: B.R. Levin \& R.E. Michod (eds.), The evolution of sex: an examination of current ideas, pp. 233-252. Sinauer Associates, Sunderland, MA.

LLOYD, D.G. 1992. Self- and cross-fertilization in plants. II. The selection of self-fertilization. International Journal of Plant Science 153: 370-380.

Lovett-Doust, J. \& L. Lovetr-Doust. 1988. Plant Reproductive Ecology, Patterns and Strategies. New York, U.S.A: Oxford University Press. xiv $+334 \mathrm{pp}$.

Luebert, F. \& P. Pliscoff. 2006. Sinopsis bioclimática y vegetacional de Chile. Editorial Universitaria, Santiago.

MAAD, J. 2000. Phenotypic selection in hawkmoth-pollinated Platanthera bifolia: targets and fitness surfaces. Evolution 54: $112-123$.

Neiland, M. \& C. Wilcock. 1998. Fruit-set, nectar reward, and rarity in the Orchidaceae. American Journal of Botany 85: 1657-1671.

Novoa, P., J. Espejo, M. Cisternas, M. Rubio \& E. Domínguez. 2006. Guía de Campo de las Orquídeas Chilenas. Corporación Chilena de la Madera. Concepción, Chile. 120 pp.

Oh, G.S., M.Y. Cheng, S.G. Chung \& M.G. Chung. 2001. Contrasting breeding systems: Liparis kumokiri and $L$. makinoana (Orchidaceae). Annales Botanici Fennici 38: 281-284.

PANNELL, J.R. 2006. Effects of colonization and metapopulation dynamics on the evolution of plant sexual systems. In: L.D. Harder \& S.C.H. Barrett (eds.), Ecology and Evolution of Flowers, pp. 223-238. Oxford University Press.

PIJL, L. VAN DER \& C.H. Dodson. 1966. Orchid flowers: their pollination and evolution. Coral Gables, FL: University of Miami Press. 404 pp.

Proctor, M., P. Yeo \& A. LACK. 1996. The Natural History of Pollination. Timber Press. Portland, Oregon. 479 pp.

Richards, A.J. 1997. Plant Breeding System. Chapman and Hall, London. xii $+529 \mathrm{pp}$.

Ruiz-Zapata, T. \& M.T.K. Arroyo. 1978. Plant reproductive ecology of a secondary deciduous forest in Venezuela. Biotropica 10: 221-230.

SchemsKe, D.W. 1980. Evolution of floral display in the orchid Brassavola nodosa. Evolution 34: 489-493.

Tremblay, R.L., J.D. Ackerman, J.K. Zimmerman \& R.N. Calvo. 2005. Variation in sexual reproduction in orchids and its evolutionary consequences: a spasmodic journey to 
diversification. Biological Journal of the Linnean Society 84: $1-54$.

Whigham, D.F. \& J. O'Neil. 1991. The dynamics of flowering and fruit production in two eastern North American terretrial orchids, Tipularia discolor and Liparis lilifolia. In: T.C.E. Wells \& J.H. Willems (eds.), Population ecology of terrestrial orchids, pp. 89-101. Academic Publishing, The Hague.

Zimmerman, J.K. \& T.M. Aide. 1989. Patterns of fruit production in a neotropical orchid: pollinator vs. resource limitation. American Journal of Botany 76: 67-73.

Recibido: 27.08.09

Aceptado: 11.01.10 